\title{
The rise of developmental genetics - a historical account of the fusion of embryology and cell biology with human genetics and the emergence of the Stem Cell Initiative
}

\author{
S H Kidson, ${ }^{1,3} \mathrm{MSc}$, PhD; R Ballo, ${ }^{1} \mathrm{MSc}, \mathrm{PhD}$; L J Greenberg, ${ }^{2,3} \mathrm{PhD}$ \\ ${ }^{1}$ Division of Cell Biology, Department of Human Biology, University of Cape Town, South Africa \\ ${ }^{2}$ Division of Human Genetics, Department of Pathology, University of Cape Town, South Africa \\ ${ }^{3}$ Institute of Infectious Disease and Molecular Medicine, University of Cape Town, South Africa
}

Corresponding author: S H Kidson (susan.kidson@uct.ac.za)

\begin{abstract}
Genetics and cell biology are very prominent areas of biological research with rapid advances being driven by a flood of theoretical, technological and informational knowledge. Big biology and small biology continue to feed off each other. In this paper, we provide a brief overview of the productive interactions that have taken place between human geneticists and cell biologists at UCT, and credit is given to the enabling environment created led by Prof. Peter Beighton. The growth of new disciplines and disciplinary mergers that have swept away division of the past to make new exciting syntheses are discussed. We show how our joint research has benefitted from worldwide advances in developmental genetics, cloning and stem cell technologies, genomics, bioinformatics and imaging. We conclude by describing the role of the UCT Stem Cell Initiative and show how we are using induced pluripotent cells to carry out disease-in-the- dish studies on retinal degeneration and fibrosis.
\end{abstract}

S Afr Med J 2016;106(6 Suppl 1):S57-S58. DOI:10.7196/SAMJ.2016.v106i6.10995

As we sit down to write about the evolving relationship between embryology, cell biology and human genetics at the University of Cape Town, it strikes us as most apposite that we are sitting in an office, now part of the Division of Cell Biology, that was once a small library in the Department of Human Genetics, a space set aside by Prof. Peter Beighton, the Head of Department, as a place to read, think and write. In the 1980s, the Department of Human Genetics occupied a floor (now called level 3) of the Anatomy Building, as well as this library and a small suite on level 6, which housed the office of the Head of Department and his clinical and administrative staff. The Department of Anatomy, headed by Prof. Benjamin Rawdon, occupied a number of other floors in the building. Anatomy was one of the founding departments in the faculty, having being established in 1912 at the Hiddingh campus, then moving to the Werner and Beit Buildings in 1929. ${ }^{[1]}$ The move to the Anatomy Building took place in the 1970s, when human anatomy and human embryology were taught largely as descriptive subjects. In the 1980s, as genetics began to take centre stage in the world of the biological sciences, anatomy departments were also modernising, embracing the disciplines of cell biology, developmental biology and anthropology into their fold and innovating with respect to how anatomy was being taught. In keeping with this trend, in the late 1980s, the Faculty of Medicine (now Health Sciences) sought to advance and enliven the teaching of histology, embryology and cell biology and to grow the research capacity in the anatomy department. The Department of Anatomy and Cell Biology was thus created, and three cell and developmental biologists were appointed: Prof. Benjamin Rawdon, Dr Susan Kidson and Dr Callie Els. It was most fortuitous that these new arrivals could benefit from being in the physical and academic proximity of the dynamic Department of Human Genetics led by Prof. Beighton.

\section{Reflecting on the origins of embryology and genetics}

Toward the end of the 19th century, Wilson, Morgan and Boveri, part of a group called 'physiological embryologists' were seeking to understand whether the elements of inheritance were to be found in the nucleus or the cytoplasm. By studying the chromosomes of sea urchins, Morgan was eventually able to provide material evidence for the concept of a gene. ${ }^{[2]}$ Although this type of genetics was originally seen as being part of embryology in the 1930s, genetics became a subject of its own, and hostilities between embryologists and geneticists began to emerge. The re-synthesis of genetics and embryology did not come easily, but a merger was achieved in the late 1960s when embryologists, cell biologists and geneticists came together in what became known as developmental genetics. These changes were timely, because many other biological revolutions were underway and new subjects had arisen: a synthesis of evolution, genetics and development resulted in the rise of the discipline EvoDevo, and powerful bioinformatics tools fuelled the genomics fire, all of which significantly advanced the discipline of developmental genetics. ${ }^{[2]}$

The stage was thus well set for cell biologists and human geneticists at the University of Cape Town (UCT) to work closely together. With common interests in genes, molecular biology and medical embryology, three staff members, Profs Raj Ramesar, Jacquie Greenberg (both in Human Genetics) and Susan Kidson (Cell Biology) saw the need for a joint honours programme, and this was launched in 1998. The academic and organisational success of this joint exercise soon led to a programme of greater expanse, culminating in the current 'Joint Honours Programme' which includes human genetics, forensic genetics, medical cell biology, medical biochemistry, immunology, microbiology and virology, physiology, radiobiology and structural biology.

\section{Research collaborations between human genetics and cell biology}

A common interest in eye development and inherited blinding conditions (and the potential of gene therapy) led to genetic and cellular studies of the retina. ${ }^{[3]}$ There was minimal evidence at the 
time that some inherited blinding conditions result from a primary insult to the retinal pigment epithelium (RPE) and not to the neural retina, as had been shown for other blinding conditions. But the decision to work on the RPE has been fortunate and productive. Prof. Raj Ramesar and cell biologist Prof. Sharon Prince have recently worked together on a mutation in the signal sequence of the carbonic anhydrase IV (CAIV) gene in an autosomal dominant form of retinitis pigmentosa (RP17 locus). ${ }^{[4]}$ The role of the RPE in spinocerebellar ataxia type 7 (SCA7) is currently being explored (Ms Sylvia Kamanzi-wa, Dr Robea Ballo and Profs Kidson and Greenberg).

The cloning of Dolly the sheep in $1997^{[5]}$ led to an unprecedented worldwide rise in levels of interest in embryos and genetics, and for the next 10 years or more we were kept well occupied by the press, the public and the scientific community, explaining what can and what cannot (or should not) be cloned, and what the moral, legal and ethical implications might be. Profs Kidson and Greenberg joined with a group of South African (SA) scientists, including Prof. Michael Pepper (University of Pretoria) and Prof. Ames Dhai (University of the Witwatersrand), who were tasked with crafting legal regulations to control human cloning (as well as stem cell research and therapy) in SA. During the same period, an international team of developmental cell biologists ${ }^{[6]}$ finally succeeded in culturing human embryonic stem cells (the inner cell mass of a blastocyst embryo) and were able to prove that they were pluripotent and able to differentiate into many different cell types of the body in vitro. The tidal wave of interest in stem cell biology, gene therapy and regenerative medicine rose to yet higher levels. As the storm broke, extraordinary claims hit the air: stem cells in all their many guises were revealed, and the extraordinary potential for research, drug discovery and therapy was announced. Many discoveries and claims have given rise to some of the most vexing biomedical and ethical issues ever faced by scientific and medical experts, the public and law makers. The storm has been further fuelled by other winds of scientific and technological change, with advances in molecular genetics, genomics, proteomics and imaging paving the way for ever more informative studies.

\section{The UCT Stem Cell Initiative and the new era}

What is so seductive about stem cells? It is the ease with which they can be harvested, their immortal state and their ability to differentiate into many of the cell types of the body. It was Dr Janine Scholefield, ${ }^{[7]}$ originally trained by Prof. Jacquie Greenberg in Human Genetics, and at the time working at the University of Oxford, who brought our attention to the new cells on the block, namely induced pluripotent stem cells (iPSC) ${ }^{[8,9]}$ It was evident to us that the time was ripe to set up a stem cell research facility at UCT. ${ }^{[10]}$ Dr Robea Ballo, also originally from the Department of Human Genetics (in the 1980s) was invited to join the group and establish the iPSC facility. She spent time in the laboratories of two collaborators at the University of Oxford (Dr Sally Cowley and Prof. Matthew Wood), where she developed her expertise in generating iPSCs. She returned to UCT in 2013 to manage the UCT stem cell facility. iPSC work is routinely conducted in the UCT facility and the technology has been and is currently the basis of a number of $\mathrm{PhD}$ theses in both human genetics (Dr Lauren Watson and Dr Danielle Smith) and cell biology (Ms Dimakatso Gumede and Ms Sylvia Kamanzi-wa). iPSC technology is time consuming and technically demanding, but the main challenge to any time-constrained student is to find a way to set up authentic disease models. Perhaps the most important of these is the ability to identify the tissues that are critical for modelling the disease in a culture dish and which would ultimately help define the physiological phenotype being investigated. Thus far, the spectrum of cells that have been generated by our students have been neurons, photoreceptors, mesenchymal cells, adipocytes and retinal pigment epithelium for conditions such as spinocerebellar ataxia type $7^{[10]}$ and hereditary familial poikiloderma. ${ }^{[1]}$

As the world turns its attention to new advances in genome engineering, so too have we, with the latest gene-editing technology, clustered regularly interspaced short palindromic repeats (CRISPR/ Cas9), coming firmly into our field of view. The technology is cost effective, uncomplicated and is able to permanently and selectively edit DNA. ${ }^{[12]}$ The CRISPR/Cas9 system is modelled on a viral defence system of microorganisms in which a pair of small RNA 'molecule scissors', as it were, are designed to a specific target site on double-stranded DNA. The RNA molecule is complementary to the DNA target and can be devised to find a binding site on any gene of interest. The simplicity of the CRISPR/Cas9 system has made it possible for researchers to edit mammalian genes in a range of different cells, thereby opening up the potential to investigate genetic diseases. The UCT Stem Cell Initiative team is currently attempting to use the CRISPR/Cas9 in iPSCs derived from patients who suffer from an autosomal dominantly inherited form of SCA7, a blinding and movement disorder. SCA7 is caused by a dynamic and unstable genetic expansion in the ATXN7 gene. ${ }^{[10]}$ The ultimate objective is to generate isogenic lines that will allow us to define the molecular phenotype of the condition. Ultimately, the consideration would be to refine the previous locally developed gene-silencing form of therapy by our ataxia and stem cell group for the treatment of this specific form of inherited ataxia. ${ }^{[7]}$ Other projects underway include the generation of isogenic lines from iPSCs generated from South African patients with an autosomal dominant form of hereditary fibrosing poikiloderma (collaboration with Prof. Bongani Mayosi) and tissue engineering of the corneal endothelium.

We look forward to the next era of biological medicine and science, where gene therapy and stem cell biology come of age.

\section{References}

1. Louw JH. In the Shadow of Table Mountain: A history of the University of Cape Town Medical School. Cape Town: Struik; 1969

2. Gilbert SF. Developmental Biology. 7th ed. Sunderlands: Sinauer Associates Inc.; 2003.

2. Gilbert SF. Developmental Biology. 7th ed. Sunderlands: Sinauer Associates Inc.; 2003.
3. Watson LM, Smith DC, Scholefield J, et al. Spinocerebellar ataxia type 7 in South Africa: Epidemiology, pathogenesis and therapy. S Afr Med J 2016;106(6 Suppl 1):S107-S109.

4. Pandor A, Ramesar R, Prince S. Cell-specific differences in the processing of the R14W CAIV mutant associated with retinitis pigmentosa 17. J Cell Biochem 2010;15(111):735-741. DOI:10.1002/ jcb. 22759

. Wilmut I, Schnieke AE, McWhir J, Kind AJ, Campbell KH. Viable offspring derived from fetal and adult mammalian cells. Nature 1997;385(6619):810-813. DOI:10.1038/385810a0

6. Tachibana M, Amato P, Sparman M, et al. Human embryonic stem cells derived by somatic cell nuclear transfer. Cell 2013;153(6):1228-1238. DOI:10.1016/j.cell.2013.05.006

Scholefield J, Greenberg LJ, Weinberg MS, Arbuthnot PB, Abdelgany A, Wood MIA. Design of RNAi hairpins for mutation-specific silencing of ataxin-7 and correction of a SCA7 phenotype. PLOS ONE 2009;4(9):e7232. DOI:10.1371/journal.pone.0007232

8. Takahashi K, Yamanaka S. Induction of pluripotent stem cells from mouse embryonic and adult 8. Takahashi K, Yamanaka S. Induction of pluripotent stem cell
fibroblast cultures by defined factors. Cell 2006;126(4):663-676.

fibroblast cultures by defined factors. Cell 2006;126(4):663-676.
9. Ballo R, Greenberg J, Kidson S. A new class of stem cells in South Africa: iPS cells. S Afr Med J Ballo R, Greenberg J, Kidson S. A new class

10. Kidson, SH, Ballo, R and Greenberg JG (2016) .Divisions of Cell Biology and Human Genetics, University of Cape Town. Stem Cell Research Initiative. Updated 2.5.2016, accessed 2.5.2016. Available from: http://stemcells.uct.ac.za

11. Smith DC, Watson LM, Greenberg JLJ, Wood MJA, Scholefield J. RNA therapy for polyglutamine neurodegenerative diseases. eLS 2013. DOI:10.1002/9780470015902.a0024909

12. Khumalo NP, Pillay K, Beighton P, et al. Poikiloderma, tendon contracture and pulmonary fibrosis: a new autosomal dominant syndrome? Br J Dermatol 2006;155(5):1057-1061. DOI:10.1111/j.13652133.2006.07473.x

13. Doudna J, Charpentier E. The new frontier of genome engineering with CRISPR-Cas9. Science 2014;346(6213):1258096. DOI:10.1126/science.1258096 